\title{
Media ethics in elections
}

The context of an election makes little difference to the way the journalist practises his or her profession. The basics are all the same. We do not adopt a different set of values because a group of politicians are vying for power.

\section{By RICHARD NAIDU}

MY VIEW on media ethics in an election context and the role of culture in media ethics is a very personal view, based on my own experiences as a journalist. Remember, this was (almost) a generation ago, in newspapers and magazines in Fiji and New Zealand, when everything was typed, three paragraphs to a page, on copy paper, stapled and subbed in red pen. Television was some threatening uncivilised thing and the Net was something you jumped over to retrieve a tennis ball.

Times and technology have changed but I don't believe the same is true of journalism ethics. The basics are the same - you just apply them in different ways. In the 1980s you didn't quote the party manifesto out of context; in the 21 st century you don't cut and paste off their website to make it look like the party is saying a different thing.

Media ethics in an election context

What context?

Elections have all the things the public - and therefore the press - love. I guess what gets people so interested in them are the twin elements of confrontation and power. Confrontation always makes good copy and there is something about power - and the winning and losing of it - that seems to capture the public's imagination, even if it is only the voters' revenge.

In my view, the context of an election makes little difference to the way the PACIFIC JOURNALISM REVIEW 7:1 200165 


\section{RICHARD NAIDU}

journalist practises his/her profession. The basics are all the same. We do not adopt a different set of values because a group of politicians are vying for power. Still, some things do change:

Our own personal contexts may change. To meet demand for resources, many of us may be taken out of our normal rounds and put into politics for the first time (or maybe the first time since the last election), which we may or may not enjoy. We are not all political animals and the political environment is very different from the courts or business or "waterfront".

$\square$ Even if we are not doing "pure" politics stories, everything gets politically hyped around election time. (About the best advice I can offer for the "nonelection" team is: Think about the political context and unless there is a story in it, ignore it and get on with doing your work).

A About the first thing that changes for a journalist covering an election is the balance of power - real or perceived. Suddenly, it appears, the tables are turned. This Government Minister who never returned your calls, brushed you aside in the hallways of Parliament, is now eating out of your hand - he is calling you and it is you who makes the play.

\section{Can we cope with this life-threatening change?}

Keep a sense of proportion. You are doing the same job you did when the Minister was ignoring you and very soon, if he gets elected, he will usually go back to ignoring you. He already knows that - do you? Don't make your judgments on the basis that this is a love affair that will last forever, that you can boost a politician's political career and there might be something in it for you. Your career - and your respectability and integrity as a journalist - lasts longer than one election cycle. Remember the converse also - most politicians can bounce back after one or two bad stories. Don't make your judgments thinking you have power over a politician's life or death.

You are not there to be liked. Closely allied to the power thing is the big chance of getting close to the big noters and enjoying their company. If that is what you are after, you will not do your job well. Just as you will be courted by some politicians, you have to be prepared to stand up to bullying from others. The press is a favourite target of politicians at election time. Politicians get personal and aggressive. This is nothing new for them, but it may be new for you. If you have a clear conscience, set your jaw and stay the course. After a particularly debilitating week at The Fiji Times it seemed to me I was being attacked at political meetings more often than the enemy party. My late friend 66 PACIFIC JOURNALISM REVIEW 7:1 2001 
John Richardson, a future editor of Islands Business, lifted my spirits by reminding me: "If you're taking flak you're usually over the target."

Play it straight. The most balanced among us have even unwitting personal and political agendas, even if it is only that we want peace and goodwill on earth. It is not for us to influence the voters on Ms X's poisonous views on peace and goodwill. Truth is an elusive thing, maybe, but a balanced news story needn't be.

Editorialising has a place. It is not, however, in the straight news stories. It might be in the "op-ed" pages or in bylined feature articles, depending on editorial policy - or even the editorial column itself. But a "think piece" should not be dressed up as a news story.

The basics continue to apply:

These are my current pet hates:

$\square$ Balance, accuracy and fairness: Apply the same standards you always should. I wonder, on reading some stories, if all journalists have actually read their codes of ethics.

$\square$ Ensure that a person attacked - and there is a lot more attacking going on (even more than usual in Fiji) in an election - gets the right of reply he/she should always have. This is something on which the media in Fiji - particularly the print media - have generally become quite lazy, being content to do a rewrite job on the rantings of some party hack who puts out a press release because he/she is offended about something s/he read about over breakfast, and then waiting to see if anything bounces back from the person attacked. If you can't be bothered getting the attacked person to reply, you need to ask yourself if there is a story at all in the first attack.

The use of so-called "unnamed sources" has become epidemic. Journalists appear to forget that they do nothing for their credibility using unnamed sources for everything. If a reader cannot judge the quality of the source biased? crazy? an inveterate exaggerator? - not only does the reader give the story little weight, but you are doing a disservice to the reader who does not know the difference. The latest crop of "unnamed sources" stories have been political stories where backbenchers complain about their leaders, etc. If politicians, especially, are that gutless, what is their point of view really worth? It is rarely worth a quote. The other cover for "unnamed sources" is the easy quote for the journalist who can t quite get anyone to say what he/she thinks the story is about, so makes up an unnamed source to do it (not all newspaper readers are completely clueless, you know). This is totally unethical: It is lying and

PACIFIC JOURNALISM REVIEW 7:1 200167 


\section{RICHARD NAIDU}

editorialising at the same time. The story must reflect the sources, not the other way around.

\section{The cultural context}

What context?

I start from a basic proposition with "culture in politics" generally, which is that I will be sensitive to culture when someone is culturally sensitive about my taxes. I have yet to see a politician forgo a Western cultural imperialist fourwheel drive, regardless of what he/she is saying about the intrusive Western media culture of those who are questioning the cost of it. And no-one has ever suggested to me that there is some traditional gesture I can make, or seek when it is time to collect my taxes, which pay for the four-wheel.

Of course, there is a cultural context. There is no need to be gratuitously insulting to anyone's culture. This is not intelligent, productive or well-behaved in any multicultural society (which in today's world, is just about everybody's). What is fair?

However, a proper and fair questioning of some cultural norm in a political context - even if controversial - is fair. It is also fair, I think, to ask a person. There was, in my time as a journalist more than one chiefly politician who used to make much of the "insults" heaped on him by his political opponents usually quite valid criticisms of the government - but thai did not prevent those chiefs from attacking their opponents when it suited them.

Fortunately, it seems to me, the tactics I referred to above seem to be in decline. Perhaps the voters have seen through these tactics - maybe, more than ever, indigenous Fijian politics is no longer a chiefly game but a commoners' one.

But fair is fair. Election politics is all about Western-style leadership and Western-style accountability; because it is funded by Western-style taxes. Noone ought to make any apologies for holding to this point of view. And I'm sure that will give us something to discuss.

Richard Naidu is a former Journalist of the Year in Fiji and is a lawyer with a Suva legal firm. He advises several media companies on defamation and other medici law. rknaidu@munroleysiaw.com.fj 